تأثير برنامج تدريبي مقترح لتظيم السرعة فائق القصر على عامل التفذية العصبية المشتق من الاماغ لاى الناشئين في السباحة

أ.د/ ليلي صلاح الدين محم سليم

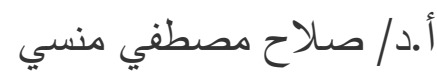

الباحث / احمد محمد عبد الحميد

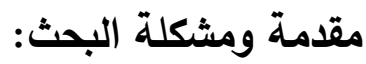

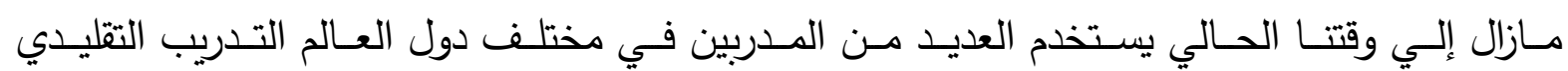
Traditional Training وتهاف إلي تتمية السعة الفسيولوجية مثل مجموعات اللاكتيك وتدريب تقليل التنفس مع التركيز علي تكملة

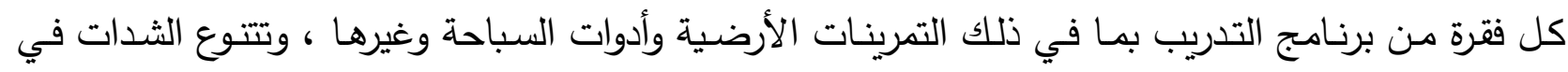

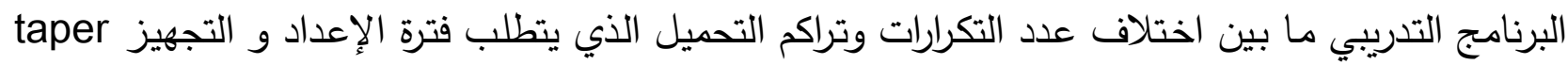
قبل البطولة الهامة والتي تستغرق حوالي اسبوعين ومن الصعب تحقيق الصتيق أفضل المستويات السباح بدون فترة التجهيز القهي للبطولة taper ، وتقوم أسس التدريب التقليدي علي آخر ما توصل إليه عليه علم التدريب من

تطبيقات نظم الطاقة الهوائية و اللاهوائية. (3: 149 )

ويعتبر ماجليثكو من أثهر من قدم تقسيمّا تفصيليّا لتتمية نظم إنتاج الطاقة في السباحة حيث اعتمد

في ذلك علي تقسيم النظام الهوائي إلي ثلاث مستويات لتنمية التحمل وتقسيم النظام اللاهوائي إلي ثنلاث

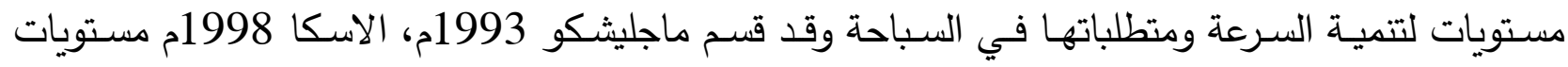
التدريب في السباحة وفقا لأنظمة الطاقة إلي ستة مستويات أساسية وهي

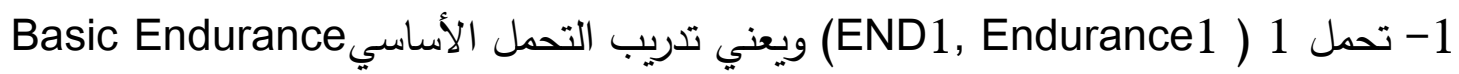

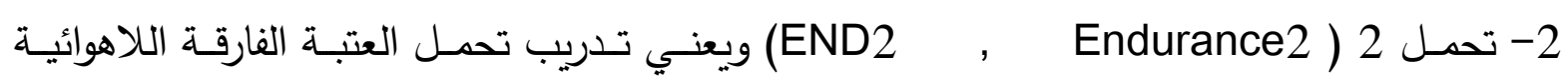

ANAEROBICTRAINING

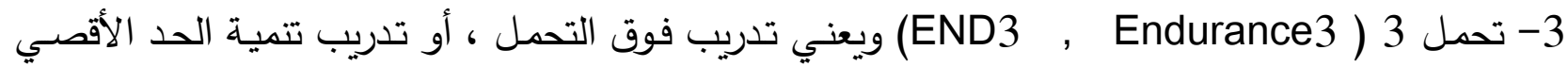
لاستهلاك الأكسجين Vo2 Max . Overload Endurance

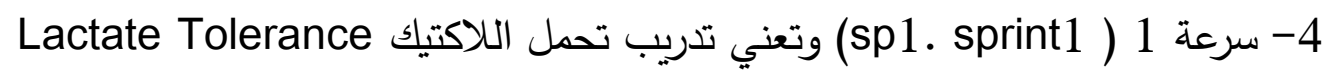

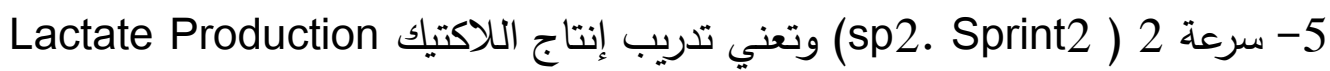

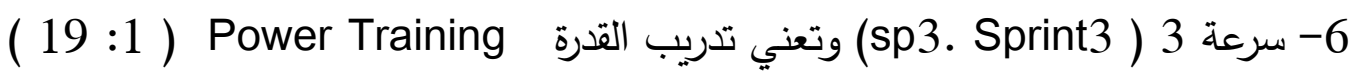
قام " ماجليشيو" (2013) بإعادة النظر في تقسيم أحمال التدريب باستخدام تدريب الألياف العضلية البيضـاء واستخدام السرعة لتتميـة التحمل ، وذلك لضمان تحسين مستويات انتاج الطاقة التي تستخدها عضلات السباح خلال الاداء، وقد أشار إلي نقاط هامة هي أن أي من الأنسجة العضلية التي يتم تدريبيها

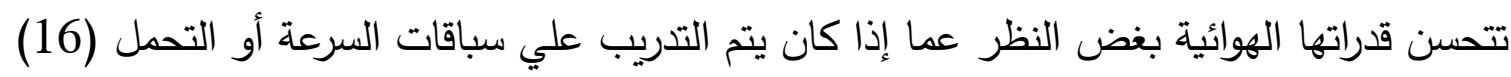


في الفترة الاخيرة منذ عام (2013) حيث ظهور الطريقة المبتكرة للعالم برنت روشال و التي تتأسس الأس التسا

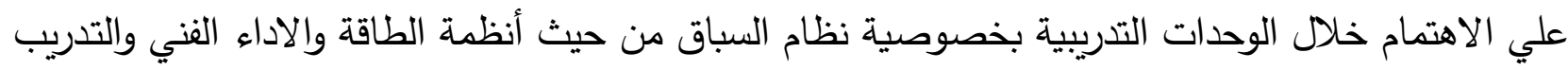

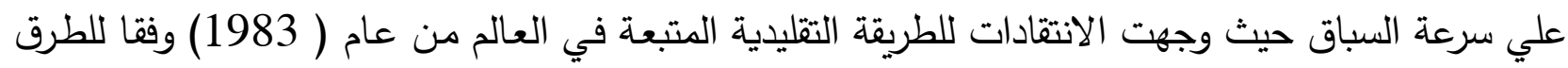

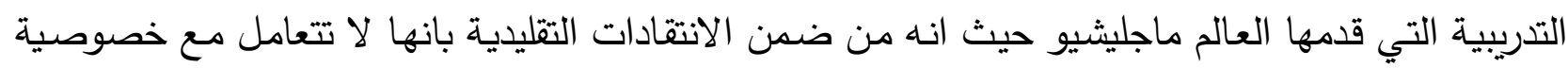
السباق ولا تعطي فرصة لتحسين أزمنة السباق و يتعرض كثير من السباحين إلي الاحتراق نتيجة للتدريب الزائد

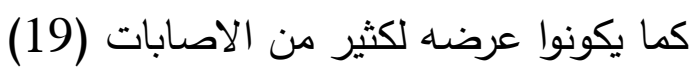

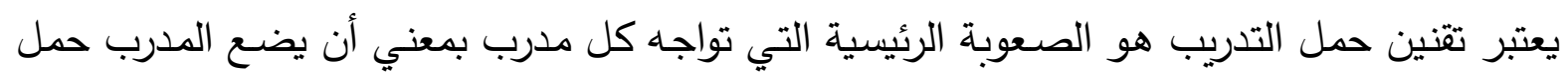

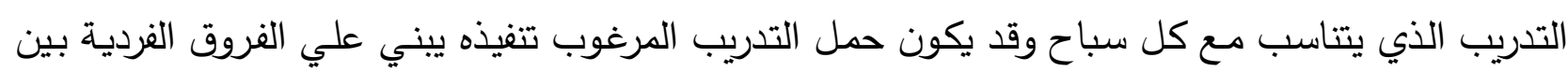

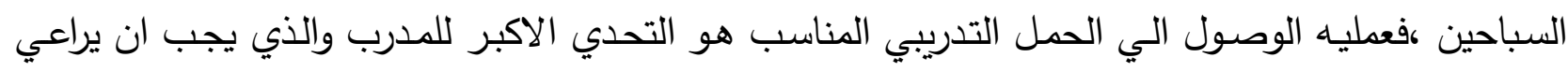

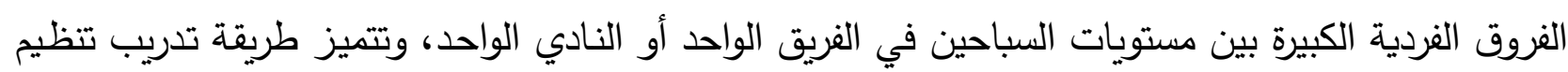

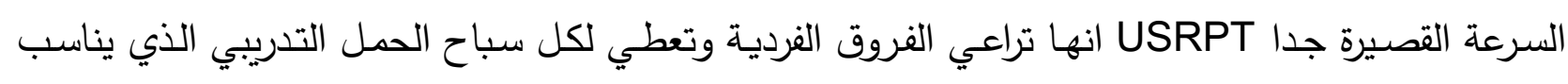

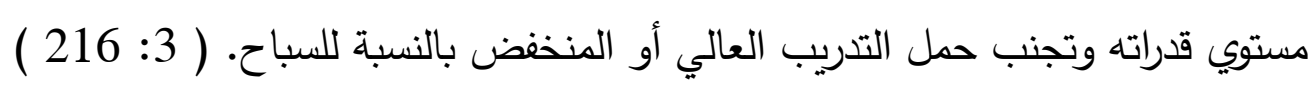

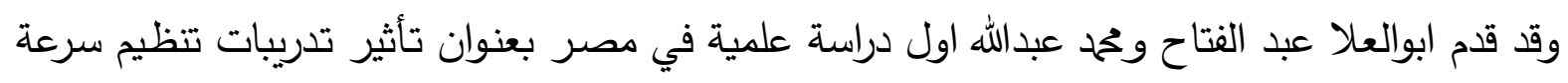

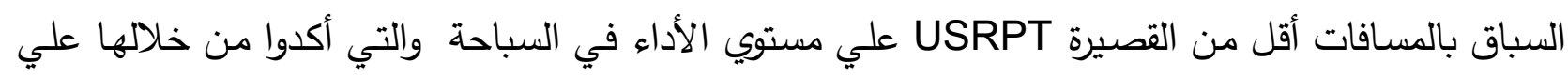

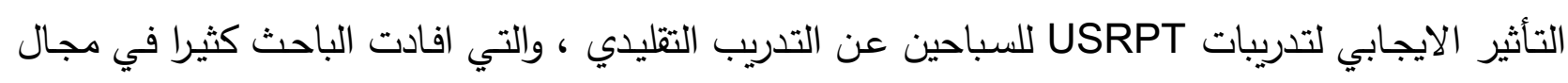
بحثه، ككونها اول مرجع يسترشد به في مجال تدريبات تنظيم سرعة السباق بالمسافات أقل من القصيرة

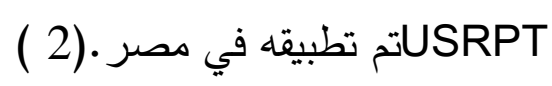
يرتبط العامل العصبي المشتق من الدماغ BDNF بعامل نمو الأعصاب وهو أول عامل تغذية عصبية

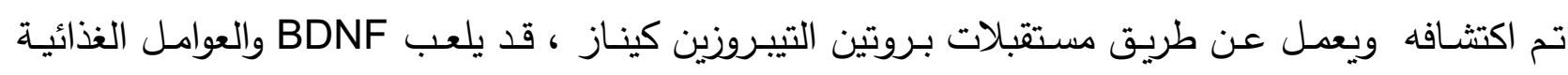

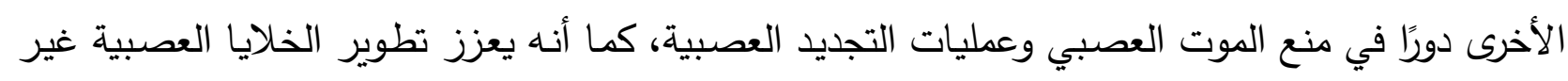
ناضجة ويعزز بقاء البالغين منها، و يلعب BDNF دورا في تكوين الذاكرة، والتشكيل المتشـابك، و فعالية

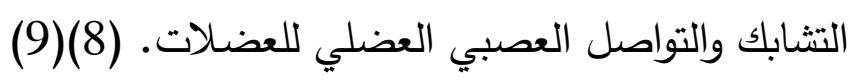

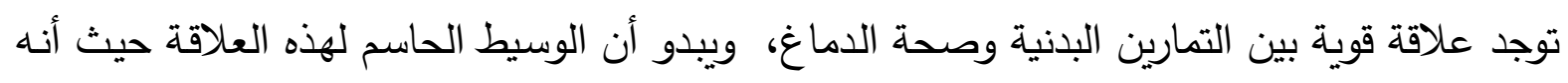

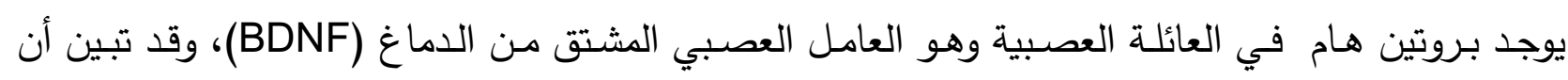

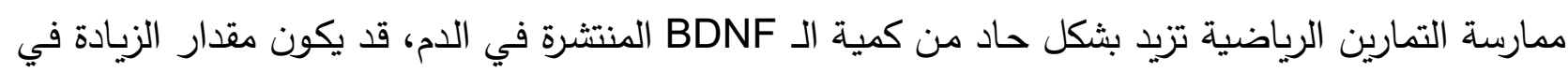

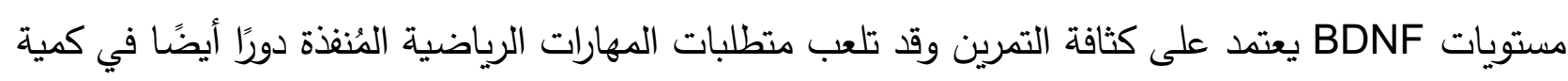

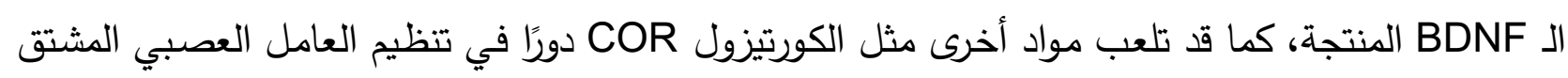

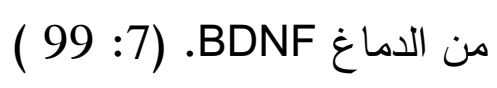

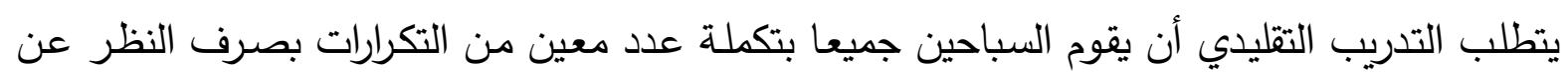

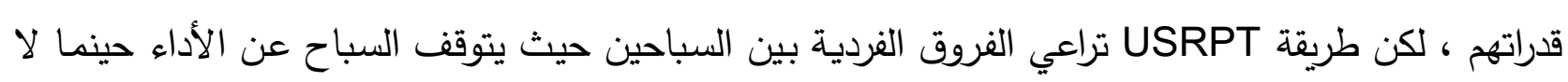

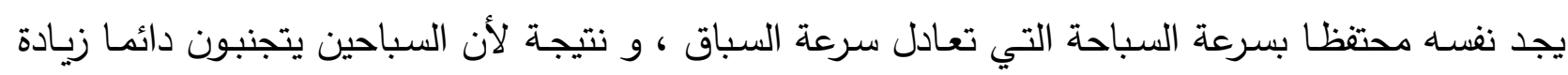


ضغط التدريب و مستويات التعب الثديدة عليهم فإنهم باستخدامهم لطريقة USRPT يتوقعون عادة تحسنا في

كل جرعة تدريبية وفي كل السباقات ، ولذلك يرتفع مستوي الدافعية لدي هؤلاء السباحين. ( 10 : 356 ) يؤدي التدريب التقليدي الذي يعتمد علي أداء تدريبات غير مرتبطة بسرعة السباق إلي تحسن أداء السباح في أداء المجموعة التدربية أي أنه يتدرب ليصبح أحسن في التدريب وليس السباق فهو يصبح جيدا ومتكيفا مع التدريب لمدة ساعتين فقط ولكنه لا يكون متكيفا لأداء السباق بسرعة عالية لمدة دقيقتين فقط أو أقل.

\section{$(277: 18)$}

قد أصبح واضحا جدا أن تدريب تتظيم السرعة القصير جدا هو طريقة التدريب التي ترتبط بين التكنيك ونظـم الطاقـة ، ولكـن السـباق أيضـا يحتـاج الـي اسـتخدام العقل لتحسين الأداء، ولا يحدث التدريب الزائد Oند التدريب بهذه الطريقة بينما هو ظاهرة عامة جدا تحدث في حالة التدريب التقليدي ، نظرا لأن طريقـة USRPT تتجنب حدوث التدريب الزائد نتيجـة لتوقف السباح عن الاستمرار في أداء تكرارات المجموعة التذرببية عندما لا يمكنه الاحتفاظ بسرعة السباحة المستهدفة، وهذه هي خبرة التعب العصبي ولا

توجد فرصة لكي يستخدم السباح سرعة سباحة أبطا من سرعة السباق. ( 10 : 189 ) نتيجة لتدريب تتظيم السرعة يكون المخ أنماط عصبية عضلية للأداء تربط بين الطاقة وتتكيك الأداء الخاصة بالسباق مما يجعل السباح يقطع مسافة السباق بسرعة منتظمة وهذا لا يتحقق إلا بعد تكرارات كثيرة لتدريب تنظيم السرعة (17: 121 ) واستكمالا علي ما سبق ذكره ، قد لاحظ الباحثون من خلال مجال عمل إحداهم كمدرب سباحة للعديد من المراحل السنية أن الكثير من المدربين لا يزالوا يستخدمون أسـاليب و طرق التدريب التقليدية، في ظل إحل احتواء هذه الطرق التقليدية علي العديد من نقاط الضعف والتي تؤثر سوف سلبيا علي مستوي السباح ومن أهمها عدم مراعاتها للفروق الفردية بين السباحين، وكذلك أيضا عدم اهتمادها بخصوصية السباق، ومن جانب اخر تكرار تعرض السباحين لظاهرة التدريب الزائد المؤقت Overreaching وصولا إلي ظاهرة التدريب الزائد Overtraining كنيجة لكثرة تعرض السباحين للإصابات حتي يتم تدهور حالاتهم الصحية والنفسية حتي يتم الوصـول إلي مرحلـة الاحتراق Burning ومن ثم التوقف عن الممارسـة نهائيـا كنتيجـة لتكرار اداء السباحين للأحمال التدريبية الغير متماشية مع قدراتهم وإمكانياتهم البدنية و الفسيولوجية، علي عكس طريقة تدريب تتظيم السرعة فائق القصر USRPT التي تضع من أهم اعتباراتها الفروق الفردية بين السباحين والتي تحمي السباحين من الوصول لأي ظاهرة ضارة من ظواهر التدريب. ومن خـلال تأسس طريقة تدريب تتظيم السرعة فائق القصر USRPT علي خصوصية السباق، أي جميع المتطلبات التي ييني عليها السباق ، حيث يتم تدريب الجهاز العصبي قبل العضلي علي تكرار أداء التدريبات بثدة عالية تماثل سرعة السباق، ولهذا اختار الباحثون بروتين BDNF ضمن اجراءات الدراسة ذلك البروتين يعطي مؤشرات علي درجة التوافق العضلي العصبي في الدم والعضلات العاملة . ومن خـلال قيام الباحثون بتأكيد الرأي القائل بأن تدريبات الثدة العالية تحقق نتائج أفضل للسباحين

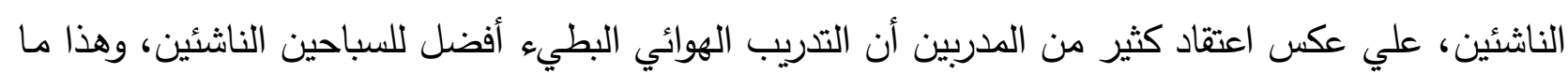


يتوافر ضمن خصائص طريقة تدريب تتظيم السرعة القصيرة جدا USRPT و التي تتميز بأداء التدريبات بشدة عالية تماثل سرعة السباق. ومن خلال الدراسة العلمية المنهجية يحاول الباحثون إجراء هذه الدراسـة لمعرفة آثر طريقة تدريب تتظيم السرعة فائق القصر USRPT علي معدلات بروتين BDNF و والمستوي الرقمي لسباحة الفراشة لمسافة 50م، - 100 اهداف البحث:

يهدف البحث الي تصميم برنامج تدريبي مقترح وفقا للمحدات الفنية لطريقة برنت روشال وذلك للتعرف علي: 1. تأثير البرنامج التدريبي المقترح علي مستويات العامل التغذية العصبي المشتق من الدماغ" BDNF ". 2. تأثير البرنامج التدريبي المقترح علي المستوي الزمني لمسافة 50م و 100م لسباحة الغراشة. تساؤلات البحث:

1. مـا هو تأثير طريقتي تدريب تنظيم السرعة فائق القصر و التدريب التقليدي علي مستويات العامل التغذية العصبي المشتق من الدماغ " BDNF " ؟ 2. مـا هو تأثير طريقتي تدريب تتظيم السرعة فائق القصر و التدريب التقليدي علي المستوي الزمني لمسافة 50م و 100م لسباحة الفراشة ؟ المصطلحات المستخدمة في البحث: التدربب القصير جدا بسرعة السباق "Ultra-Short-Race-Pace-Training " بأنه تدريب يحتوي علي سباحة مجموعات تدريبية عالية الثدة وبسرعه اداء تتساوي مع سرعة اداء السباح في السباق وعند تحقيق ذلك يتم التدرج بسرعة الاداء بهدف اتاحسة الفرصـة للسباح لقطع اكبر مسـافة ممكنة خـلال التدريب بسرعة السباق وتتشكل المجموعات التدريبية بأكبر عدد من التكرارات لمسافات قصيرة جدا ولفترات راحة لا تزيد عن 20 ثانية.(3) التدربب التقليدي" Traditional Training " هو التدريب بأحجام عالية و بالتأكيد علي شدة الأكسدة aerobic " Brain-Derived-Neurotropic-Factor " BDNF بروتين هو عامل التغذية العصبية المشتق من الدماغ ، والمعروف أيضًا باسم BDNF هو بروتين يتم تشفيره بالبشر، BDNF هو عضو في عائلة "neurotrophin" هو احد عوامل النمو ، والتي ترتبط بعامل نمو الأعصاب NGF وهو مؤشر هام وفعال علي درجة التوافق العضلي العصبي العضلي العاملة في اي حركة او نشاط وبلغت معدلاته اثناء الراحة تتراوح بين 1.2 × 10.1 إلي 2.0 × 10.9 حيث تتحدد هذه المعدلات وفقا لنوع وشكل النشاط الممارس ( 12 )( 13 ). 
أستخدم الباحثون المنهج التجريبي، وقد تم الاستعانة بأحد التصميمات التجريبية وهو التصميم التجريبي لمجمـوعتين مجموعـة تجريبيـة ومجموعـة ضـابطة بإسـتخدام القيـاس القبلـي والبعدي وذلك لملائمتـه لطبيعـة البحث.

\section{مجتمع البحث}

تمثل مجتمع البحث هم لاعبين السباحة بنادي بلاتينوم بالتجمع الخامس و ان يكونوا مسجلين بالاتحاد المصري للسباحة للموسم التدريبي 2020 / 2021 و بلغ عدد افراد المجتمع 40 لاعب ولاعبة عينة البحث

اختيـار البـاحثون عينـة البحـث بالطريقـة العدديـة مـن ناشـئى السـباحة بنـادي بلاتينـوم ويتـرواح عـدهم

(16 لاعب ولاعبة ) وفى المرحل السنية بين (13 - 14 ) سنة لاجراء الدراسة عليهح •

$$
\text { جدول ( } 1 \text { ( ) }
$$

المتوسطات الحسابية والانحرافات المعيارية ومعاملات الالتواء للمتغيرات الوصفية لعينة البحث ن=16

\begin{tabular}{|c|c|c|c|c|c|c|c|}
\hline $\begin{array}{l}\text { الالتواء } \\
\text { التاملات }\end{array}$ & الوسيط & اكبر قيمة & اقل قيمة & الالمعرافية & المستوسطية المسات & وحدات & المتغيرات \\
\hline .000 & 13.50 & 14.00 & 13.00 & .516 & 13.50 & سنة & العمر \\
\hline .019 & 161.50 & 170.00 & 151.00 & 6.27 & 160.50 & سم & الطول \\
\hline-.355 & 55.00 & 63.00 & 40.00 & 6.24 & 52.68 & كجم & ل الوزن \\
\hline-1.077 & 20.63 & 21.80 & 18.03 & .975 & 20.40 & كجم/م2 & مؤشر كتلة الجسم \\
\hline
\end{tabular}

يتضـح من نتائج الجدول (1) أن قيم معاملات الالتواء في المتغيرات الوصفية لعينـة البحث تراوحت بين (-1.077، 0.019) أي انحصرت بين ( د3 ) مما يدل على اعتدالية البيانات وتجانس عينة البحث في هذه - المتغيرات وبائل وأدوات جمع البيانات:

ادوات جمع البيانات الخاصة بالمتفيرات الفسيولوجية : أنابيب بلاستيك لتجميع وحفظ الدم بها. حقن بلاستيك لأخذ عينات الدم وتستخدم لمرة واحدة. محلول لمنع تجلط الدم داخل الأنابيب. وعاء باه ثلج لحفظ عينات الدم لحين تحليلها ICE BOX مركب الهيبارين لحفظ الدم لنقل العينات. قطن طبي، كحول للتطهير ، ولصق طبي. سنتيمتر ميزان طبي 
استمارات تسجيل بيانات وقياسات العينة. خطوات أجراء الاراسة

إجراء القياس القبلى فى المتغيرات قيد البحث .

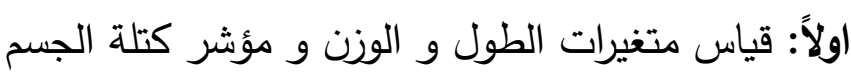

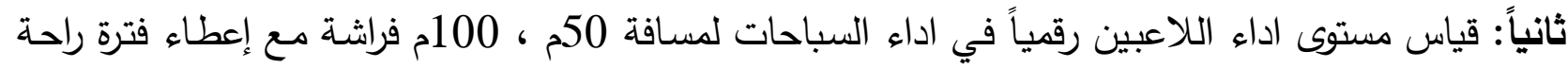

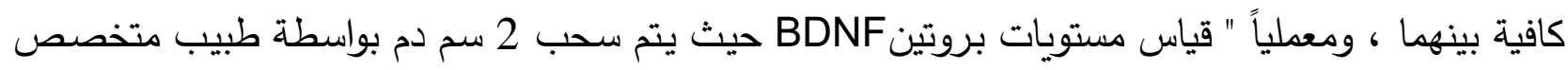

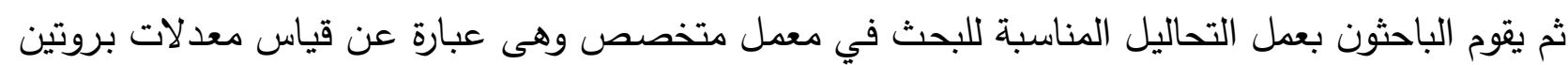

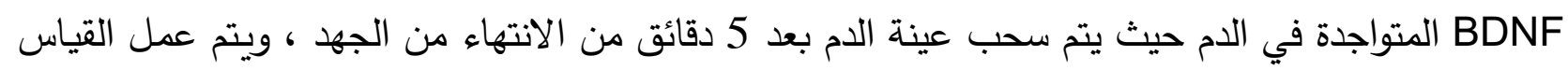

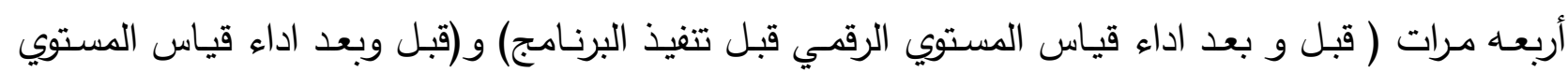

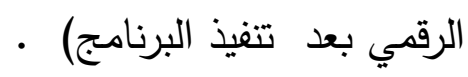
البرنـامج التـدريبي قـام البـاحثون بوضـع برنـامج تدريبي يستهدف تحسين الصـفات الفسيولوجية والرقميـة

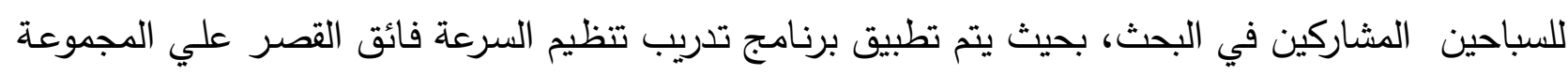

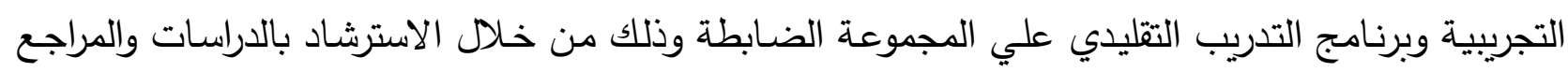

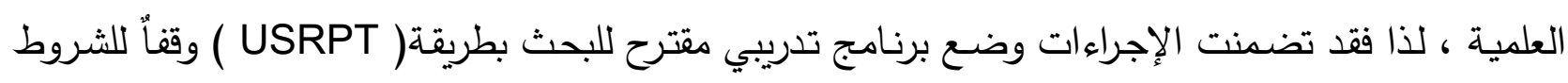

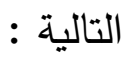

يني البرنامج علي تسجيل أفضل ازمنة للسباحين تم تحديد الهدف من تتفيذ البرنامج من خلال تحديد الزمن المستهدف لكل سباح بما يفوق أفضل الأزمنة التي

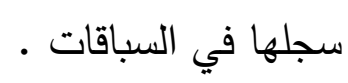

تنفيذ البرنامج التدريبي بواقع 8 مرات اسبوعياً زمن كل وحدة تدريبية يتراوح ما بين ساعة ونصف إلي سرات ساعتين

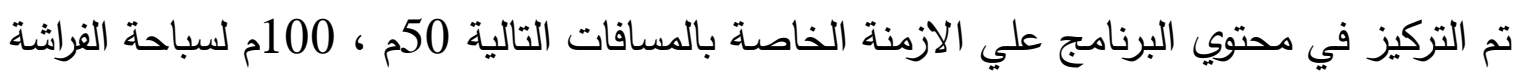

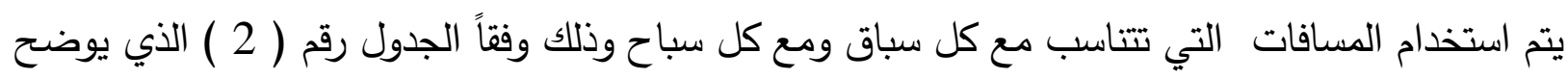
جدول رقم (2) ذلك

يوضح المسافات المتكررة لتدريبات USRPT لمسافات السباق

\begin{tabular}{|c|c|c|c|c|c|c|}
\hline \multicolumn{7}{|c|}{ مسافات السباق } \\
\hline 1500 & 800 & 400 & 200 & 100 & 50 & مسافة \\
\hline & & & & & $x$ & 12.5 \\
\hline & $x$ & $x$ & $x$ & $x$ & $x$ & 25 \\
\hline$x$ & $x$ & $x$ & $x$ & $x$ & & 50 \\
\hline$x$ & $x$ & $x$ & $x$ & & & 75 \\
\hline$x$ & $x$ & & & & & 100 \\
\hline
\end{tabular}

$(22: 21)$ 
تم استخدام التكرارات التي تتناسب مع كل سباق مع كل سباح

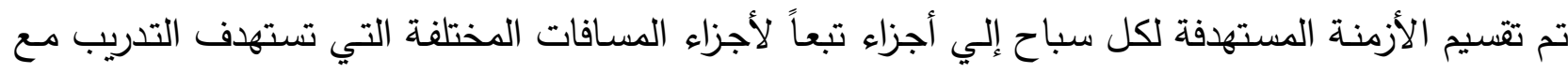
تحديد التكرارت وفقاً لما لتصميم Rushall وفقاً لما يلي: جدول رقم (3) (3)

يوضح الحد الأقصي لعدد التكرارات التي يؤديها السباح اثناء اداء تدريبات USRPT لكل سباق

\begin{tabular}{|c|c|c|c|c|c|c|}
\hline & & & & & & مسافات السباق \\
\hline \multirow[t]{3}{*}{1500} & 800 & 400 & 200 & 100 & 50 & | مسافة \\
\hline & & & & & $6 \times 4$ & 12.5 \\
\hline & & 40 & 40 & 30 & تبعا للفروق & 25 \\
\hline 50 & 50 & 30 & 30 & 20 & & 50 \\
\hline $35-30$ & 40 & 24 & 20 & & & 75 \\
\hline $30-25$ & 30 & & & & & 100 \\
\hline
\end{tabular}

(27:21)

تم إتباع الإرشادات الخاصة بكل مرحلة عمرية طبقاً لما ذكره 2018م Rushall في اقترحات تطوير السباحة

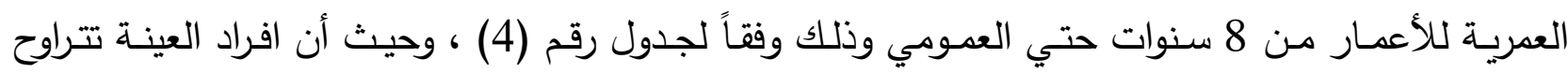

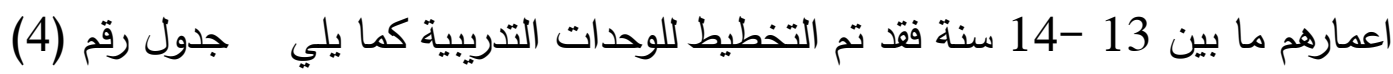
يوضح عدد الوحدات التدريبية بطريقة ( USRPT ) للمراحل السنية المختلفة ليطية

\begin{tabular}{|c|c|c|c|}
\hline زمن الوحدات & 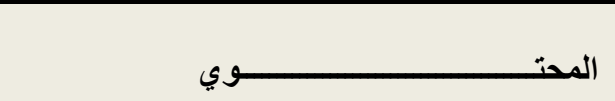 & في الاسبوع الوحدات & العمر بالسنة \\
\hline 1 & بهجة + مرح + تكنيك & 3 & 8 \\
\hline 2 ساعة & بهجة + مرح + تكنيك & 4 & 9 \\
\hline 3-1 ساعة & مهارات + تكنيك + بهجة و متعة & 5 & 10 \\
\hline 1- 3 ساعة & مهار ات + تكنيك + تشلية و متعة & 6 & 11 \\
\hline 2 مرة - 3 ساعة & مهار ات + تكنيك + تسلية و انجازات & 8-7 & 12 \\
\hline 2 مرة - 6 ساعة & مهارات + تكنيك + تدريب منافسات و انجازات & 8 & بعد البلوغ \\
\hline 2 مرة - 5-4 ساعة & للمهارات + تكنيك + استراتيجية السباق +التأهيل & $9-8$ & $14+$ \\
\hline
\end{tabular}

\section{(7: 21$)$}

تصميم سجل خاص لكل سباح يتم تسجيل فيه ارقام سباقاته المستهدفة وازمنة مسافات التدريب القصيرة لكل سباق بطريقة ( USRPT ) ، ويقوم أيضا كل سباح بتسجيل عدد محاولاته خلال كل تمرين وذلك في السجل الخاص به

عمل جلسة خاصـة مع كل سباح يسلم له فيها الجدول الخاص بتحديد أزمنة المسافات المستهدفة في التدريب لكل سباق ، مع التأكيد علي حفظها وتذكرها والتي يستهف تحقيقها خلال التدريب والذي ينتهي في حالة عمل محاولتين فاشلتين في تحقيق الزمن المستهدف. 
كما قام الباحث بمراعاة الأسس الفسيولوجية للبرنامج التدريبي و التي تبدأ بالاحماء الجيد قبل نزول الماء وذلك الكئ

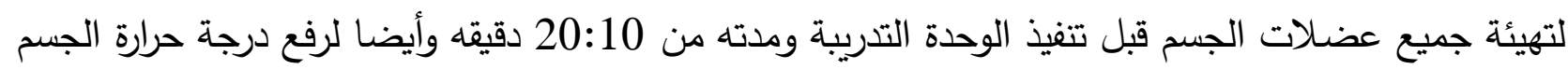

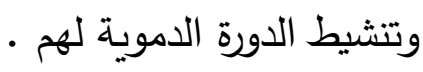
هدف البرنامج : يهدف البرنامج التدريبي المقترح للبحث الي معرفة تأثير برنامج تدريبي مقترح لتنظيم السرعة

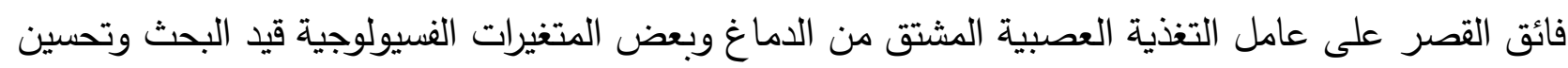

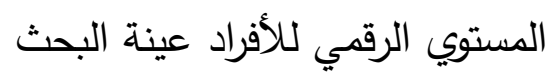

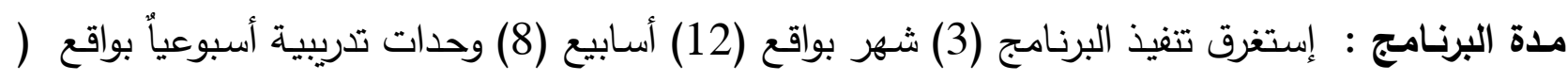

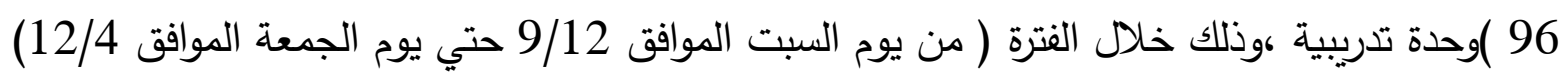

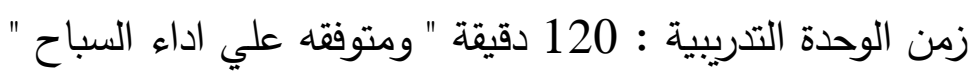

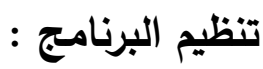

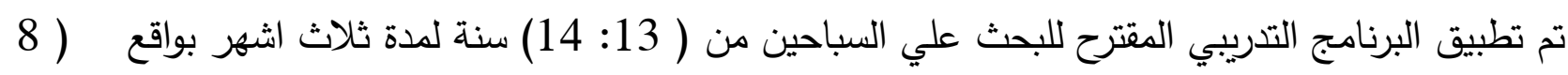

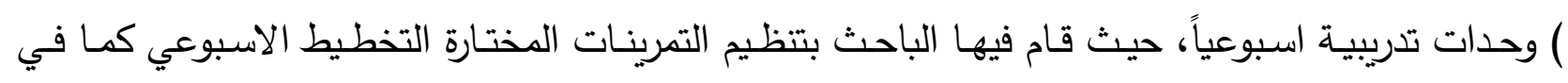

الجدول رقم (5) أندان

نموذج لوحدة تدريبية مدتها ساعتين مع ثلاث مجموعات رئيسية ومجموعة مهارة واحدة:

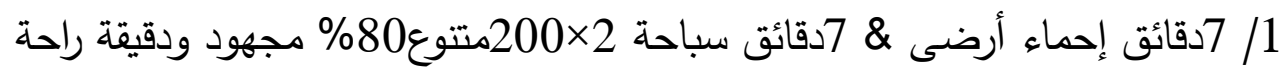
2/ رجلين دولفنية تحت الماء م15×12 (الرجلين معًا) @ 15 4انانية

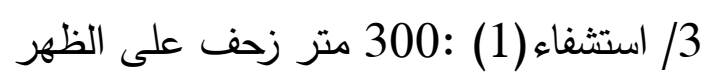

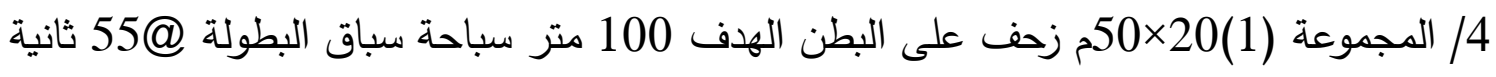

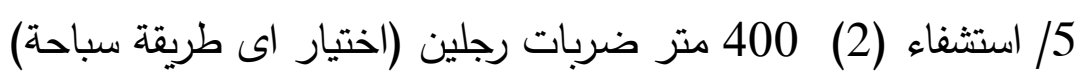

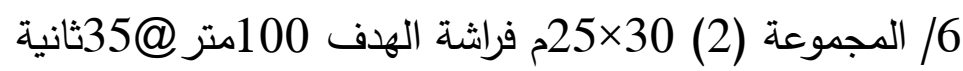

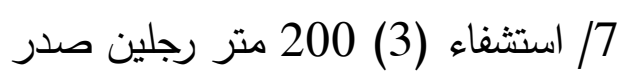

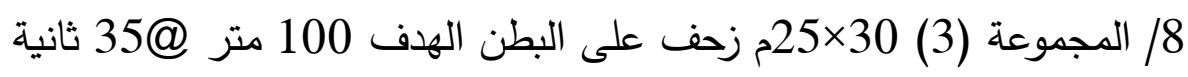
$(@=$ On $)$

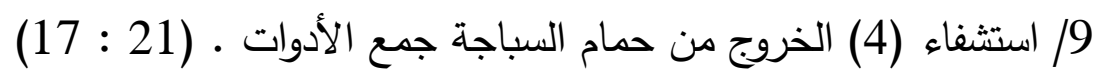
جدول رقم ( 5 ( )

محتوي الوحدات التدريبية قيد البحث تخطيط المسافات المحددة و السباحات المحددة لعينة البحث وفقاً لعدد (5 العدات

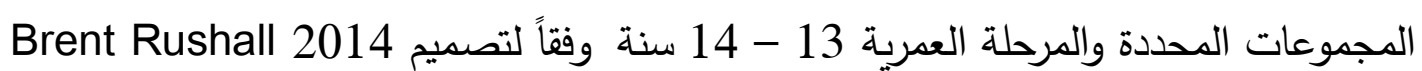

\begin{tabular}{|c|c|c|c|}
\hline المرحلة الثالثة & المرحلة الثانية & المرحلة الاولي & \\
\hline اربع استابيع & اربع اسابيع & اربع اسابيع & \\
\hline التخريب علي السباق التخصصي & تخرة - تخصي علي سباق 50 م حرة و 100 م & التمضيع من تلبريبات تحسن البرنامن بعمل & الاسبوع الاول \\
\hline التخريب علي السباق التخصصي & تخصصب علي سباق 50 م تخصص و & حراية التدريب علي سباق 50 ـ & الاسبوع الثاني \\
\hline
\end{tabular}




\begin{tabular}{|c|c|c|c|}
\hline لمسافة 100م & 100 م حرة & 100 & \\
\hline التخديب علي السباق التخصصي & ترة - تخصص علي سباق 50 م حرة و 100 م & بلاية التدريب علي سباق 50 - & الاسبوع الثالث \\
\hline التخديب علي السباق التخصصي & 100 م مرة حرة علي سباق 50 م مرة تخصص و & فراشة التريب علي سباق 50 - 100 & الاسبوع الرابع \\
\hline
\end{tabular}

• محاور البرنامج التقليدي باستخدام تقسيمات ماجليشيكو للمجموعة الضابطة: - المرحلة السنية 13-14 سنة

- عدد فترات التدريب:7 فى الاسبوع ما عدا الأثثين راحة علما بأن التدريب يوم السبت صباحا ومساءا - زمن الوحدة التدريبية ساعتين - محتوى التدريب (الثدة العالية - الحمل الزائد - التكنيك) تم استخدام تقسيمات ماجلثيكو (التحمل الاساسى- العتبة الفارقة - الحمل المكثف - انتاج اللاكتات- تحمل

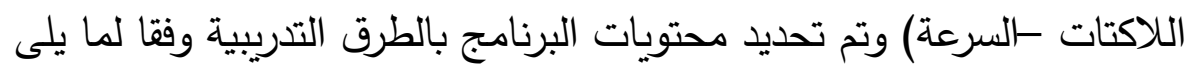

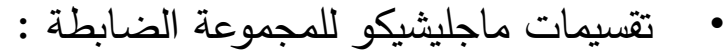

التدريب عند كل معدل ضربات القلب 120ن/ق يمكن أن يمدنا بالاستثفاء ولكن يعطي فوائد قليلة للتدريب.

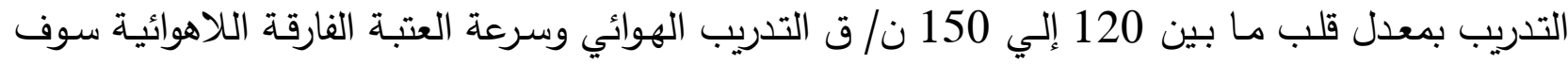

يضع الساحين في منطقة تدريب تحمل 1. التدريب لمعدل القلب ما بين 150- 170 ن / ق أو أسرع من سرعة العتبة الفارقة التلاهوائية سوف يضع السباحين في منطقة تدريب تحمل 2. السرعه من 10- 20 ثانية من 2 إلي 1 نسبه العمل / الراحة سوف يضع السباحين في منطقة تحمل تدريب 3 تحمل 3 الجها السريع من 1 إلي 3 / ق 10 استمرارية علي 1 إلي 1 نسبة العمل / الراحة سوف يضع السباحين في منطقة تدريب التحمل 3 . الجهد السريع من 10- 30 ثانية علي من 1 إلي 3 أو نسبة العمل/الراحة يزيد قدرة الضربات وأقصي سرعة . إجراء القياس البعدى فى المتغيرات قيد البحث يتم عمل القياسات البعدية لعينة قيد البحث بنفس ترتيب القياسات القبلية بعد الانتهاء من تطبيق البرنامج

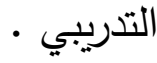

\section{المعالجات الإحصائية المستخدمة}

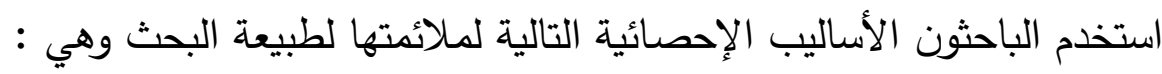

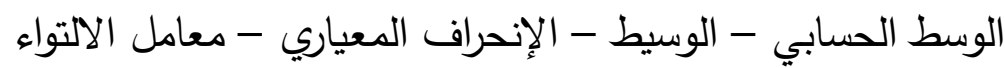

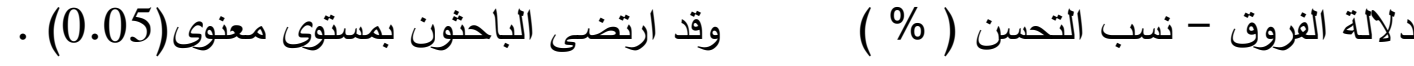




$$
\text { جدول ( } 6 \text { ( }
$$

المتوسطات الحسابية والانحرافات المعيارية ومعاملات الالتواء في القياسات القبلية لعينة البحث التجرببية

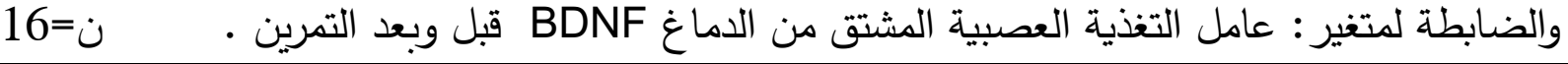

\begin{tabular}{|c|c|c|c|c|c|c|c|c|}
\hline الالتواء & الوسيط & اكبر قيمة & اقل قيمة & المعياري & الحسابي & والقياس & المتغيرات & p \\
\hline-.124 & 10.90 & 11.50 & 10.10 & .497 & 10.75 & $\mathrm{ng} / \mathrm{ml}$ & \multirow{2}{*}{ BDNF } & \multirow[b]{2}{*}{ 星. } \\
\hline .041 & 1.55 & 2.00 & 1.20 & .254 & 1.56 & $\mathrm{ng} / \mathrm{ml}$ & & \\
\hline-.107 & 11.85 & 12.40 & 11.10 & .478 & 11.73 & $\mathrm{ng} / \mathrm{ml}$ & \multirow{2}{*}{ BDNF } & 7 \\
\hline .066 & 2.45 & 2.90 & 2.10 & .236 & 2.48 & $\mathrm{ng} / \mathrm{ml}$ & & \\
\hline
\end{tabular}

يتضح من نتائج الجدول (6) أن قيم معاملات الالتواء في المتغيرات لعينـة البحث تراوحت بين (0.66،-

1.24) أي انحصرت بين( 3 (3 ) مما يدل على اعتدالية البيانات وتجانس عينة البحث في هذه المتغيرات .

$$
\text { جدول ( } 7 \text { ( ) }
$$

المتوسطات الحسابية والانحرافات المعيارية ومعاملات الالتواء في القياسات القبلية لعينة البحث التجربية و

\begin{tabular}{|c|c|c|c|c|c|c|c|c|}
\hline الالتواء & الوسبط & اكبر قيمة & اقل قيمة & الالمعياري & المستوسطي & والقياس & المتغيرات & p \\
\hline 1.21 & 35.14 & 36.87 & 34.54 & .771 & 35.39 & ث & 50متر فراشة & 1 \\
\hline .611 & 1.15 & 1.18 & 1.14 & .012 & 1.15 & ق & 100متر فراشة & 2 \\
\hline
\end{tabular}

$$
\text { الضابطة في المستوي الزمني لمسافة 50م و 100م لسباحة الفراشة ن=16 }
$$

يتضـح من نتائج الجدول (7) أن قيم معاملات الالتواء في المتغيرات لعينـة البحث تراوحت بين (1.210.611) أي انحصرت بين( 3 (3 ) مما يدل على اعتدالية البيانات وتجانس عينة البحث في المستوي الزمني لمسافة 50م و 100م لسباحة الفراشة.

$$
\text { جدول ( } 8 \text { (a) }
$$

\begin{tabular}{|c|c|c|c|c|c|c|c|}
\hline \multirow[t]{2}{*}{ قيمة "ت" } & \multicolumn{2}{|r|}{ القياس البعدى } & \multicolumn{2}{|r|}{ القياس القبلى } & \multirow{2}{*}{ القياس } & \multirow[t]{2}{*}{ المتغيرات } & \multirow[t]{2}{*}{ p } \\
\hline & $\varepsilon$ & م & $\varepsilon$ & r & & & \\
\hline-21.60 & .180 & 2.48 & .264 & 1.48 & $\mathrm{ng} / \mathrm{ml}$ & RDNE & \\
\hline-17.44 & .539 & 11.86 & .520 & 10.85 & $\mathrm{ng} / \mathrm{ml}$ & BDNF & 3 \\
\hline-80.17 & .582 & 16.86 & .198 & 2.37 & $\mathrm{ng} / \mathrm{ml}$ & DOIC & 可羿 \\
\hline-115.25 & 1.37 & 67.48 & .522 & 11.78 & $\mathrm{ng} / \mathrm{ml}$ & BDNF & .3 \\
\hline
\end{tabular}

دلالة الفروق بين نتائج القياسات القبلية - البعدية للمجموعة التجريبية في متغيرات عامل التغذية العصبية المشتق من الدماغ BDNF قبل وبعد التمرين ن=8

$0.05>0$ قيمة " ت " الجدولية عند مستوى > 0.05= 1.89 
يتضـح من نتائج الجدول (8) وجود فروق دالة إحصـائياً عند مستوى > 0,05 بين نتائج القياسين القبلي والبعدي لعينة البحث التجريبية في متغير : عامل التغذية العصبية المشتق من الدماغ قبل وبعد التمرين لصالح

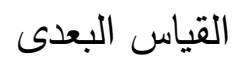

جدول (9)

دلالة الفروق بين نتائج القياسات القبلية - البعدية للمجموعة التجريبية فى المستوي الزمني لمسافة 50م و

100م لسباحة الفراشة ن= 8

\begin{tabular}{|c|c|c|c|c|c|c|c|}
\hline \multirow[t]{2}{*}{ قيمة "ت" } & \multicolumn{2}{|r|}{ القياس البدى } & \multicolumn{2}{|r|}{ القياس القبلى } & \multirow{2}{*}{ القياسات } & \multirow[t]{2}{*}{ المتغيرات } & \multirow[t]{2}{*}{ م } \\
\hline & $\varepsilon$ & p & $\varepsilon$ & P & & & \\
\hline 2.80 & 1.53 & 32.74 & .870 & 35.59 & $\dot{\Delta}$ & 50متز فراشة & 2 \\
\hline 2.99 & .060 & 1.07 & .012 & 1.15 & ق & 100متر فراشة & 4 \\
\hline
\end{tabular}

* دال احصائياً عند مستوى > 0.05

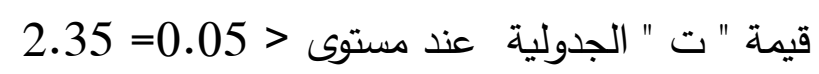

يتضح من نتائج الجدول (9) وجود فروق دالة إحصائياً عند مستوى >

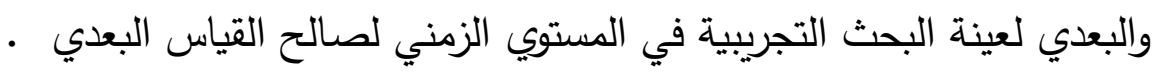
جدول (10)

دلالة الفروق بين نتائج القياسات البعدية للمجموعة التجريبية و الضابطة في متغيرات: عامل التغذية العصبية

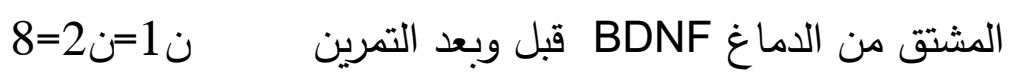

\begin{tabular}{|c|c|c|c|c|c|c|c|}
\hline \multirow[t]{2}{*}{ ققيمة "ت" } & \multicolumn{2}{|c|}{ المجموعة الضابطة } & \multicolumn{2}{|c|}{ المجموعة التجريبية } & \multirow{2}{*}{ القياس } & \multirow[t]{2}{*}{ المتغيرات } & \\
\hline & $\varepsilon$ & P & $\varepsilon$ & P & & & \\
\hline-2.38 & .195 & 2.71 & .180 & 2.48 & $\mathrm{ng} / \mathrm{ml}$ & DONC & \\
\hline-.467 & .416 & 11.97 & .539 & 11.86 & $\mathrm{ng} / \mathrm{ml}$ & BDUNF & ?.7. \\
\hline 29.81 & .496 & 8.78 & .582 & 16.86 & $\mathrm{ng} / \mathrm{ml}$ & PDNC & 司 \\
\hline 109.08 & .416 & 11.97 & 1.37 & 67.48 & $\mathrm{ng} / \mathrm{ml}$ & BDNF & 马. \\
\hline
\end{tabular}

قيهـة " ت " الجدوليـة عند مستوى > 0.05= 1.89 يتضـح مـن نتائج الجدول (10) وجود فروق دالـة

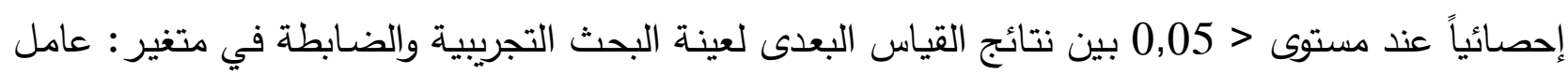

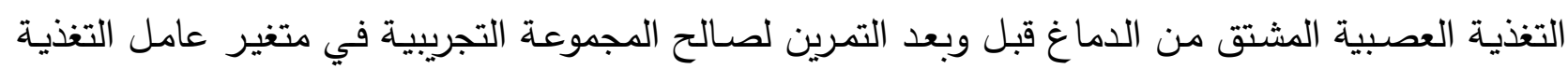
العصبية المتشق من الدماغ BDNF.

$$
\text { جدول (11) }
$$

دلالة الفروق بين نتائج القياسات البعدية للمجموعة التجريبية والضابطة فى المستوي الزمني لمسافة 50م و

\begin{tabular}{|c|c|c|c|c|c|c|c|}
\hline \multirow[t]{2}{*}{ قيمة "ت" } & \multicolumn{2}{|c|}{ المجموعة الضابطة } & \multicolumn{2}{|c|}{ |المجموعة التجريبية } & \multirow{2}{*}{ القياس } & \multirow{2}{*}{ المتغيرات } & \multirow[t]{2}{*}{ م } \\
\hline & $\varepsilon$ & p & $\varepsilon$ & p & & & \\
\hline-.741 & .534 & 33.34 & 1.53 & 32.74 & ڤ & 50متر فراشة & 2 \\
\hline-1.51 & .017 & 1.11 & .060 & 1.07 & ق & 100متر فراشة & 4 \\
\hline
\end{tabular}

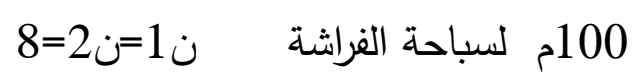




$$
\begin{aligned}
& \text { * دال احصائياً عند مستوى > } 0.05 \\
& \text { قيمة " ت " الجدولية عند مستوى > } 2.35=0.05
\end{aligned}
$$

يتضح من نتائج الجدول (11) وجود فروق دالة إحصائياً عند مستوى > 0,05 بين نتائج القياس البعدى

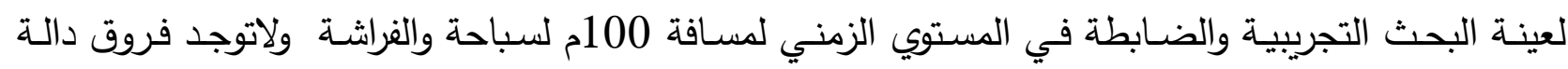
إحصائياً عند مستوى > 0,05 بين نتائج القياس البعدى لعينة البحث التجريبية والضابطة في المستوي الزمني لمسافة 50م لسباحة الغراشة .

\section{جدول ( 12 )}

نسب التحسن بين نتائج القياسات القبلية - البعدية لعينة البحث التجريبية في متغيرات : عامل التغذية

\begin{tabular}{|c|c|c|c|c|c|c|c|}
\hline \multirow{2}{*}{ نسبة التحسن } & \multicolumn{2}{|r|}{ القياس البعدى } & \multicolumn{2}{|r|}{ القياس القبلى } & \multirow{2}{*}{ والقياس } & \multirow{2}{*}{ المتفيرات } & \multirow{2}{*}{ s } \\
\hline & $\varepsilon$ & p & $\varepsilon$ & p & & & \\
\hline$\% 67,56$ & .180 & 2.48 & .264 & 1.48 & $\mathrm{ng} / \mathrm{ml}$ & RDNE & \\
\hline$\% 9,31$ & .539 & 11.86 & .520 & 10.85 & $\mathrm{ng} / \mathrm{ml}$ & BDINF & \\
\hline$\% 611,39$ & .582 & 16.86 & .198 & 2.37 & $\mathrm{ng} / \mathrm{ml}$ & RDNF & 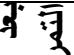 \\
\hline$\% 472,83$ & 1.37 & 67.48 & .522 & 11.78 & $\mathrm{ng} / \mathrm{ml}$ & & .3 \\
\hline
\end{tabular}
العصبية المشتق من الدماغ BDNF قبل وبعد التمرين

يتضح من نتائج الجدول (12) أن نسب التحسن بين نتائج القياسين القبلي والبعدي لعينة البحث في

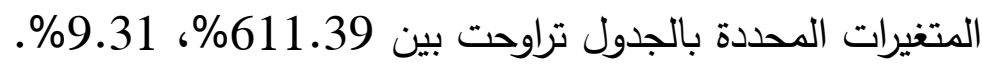

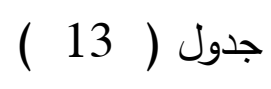

\begin{tabular}{|c|c|c|c|c|c|c|c|}
\hline \multirow{2}{*}{ نسبة التحسن } & \multicolumn{2}{|r|}{ القياس البعدى } & \multicolumn{2}{|r|}{ القياس القبلى } & \multirow{2}{*}{ القياس } & \multirow{2}{*}{ المتغيرات } & \\
\hline & $\varepsilon$ & 5 & $\varepsilon$ & a & & & \\
\hline$\% 8,70$ & 1.53 & 32.74 & .870 & 35.59 & ث & 50متر فراشة & 2 \\
\hline$\% 11,95$ & .060 & 1.07 & .012 & 1.15 & ق & 100متر فراشة & 4 \\
\hline
\end{tabular}

نسب التحسن بين نتائج القياسات القبلية - البعدية لعينة البحث التجريبية في المستوي الزمني لمسافة 50م و 100م لسباحة الفراشة

يتضح من نتائج الجدول (13) أن نسب التحسن بين نتائج القياسين القبلي والبعدي لعينة البحث في المتغيرات المحددة بالجدول تراوحت بين 11.95\%، 8.70\% 
في ضوء مـا سبق من عرض لنتائج البحث يتم مناقشـة النتائج علي النحو التالي أولاً من خـلال تسـاؤلات البحث وتحقيقاً لأهدافه ووفقاً للبيانـات التى تم التوصل إليها والتى تمت معالجتها إحصـائياً ، سوف يقوم الباحثون بمناقشـة النتائج وتفسيرها مـع الإستشهاد بالمراجع العلمية والدراسـات المرجعية وفقا لترتيب فروض البحث ثانياً من خلال التحقق من نسب تحسن متغيرات البحث ومقارنتها مع الدراسات المرجعية وذلك للتأكد من تحقيق ذلك التحسن. مـا هو تأثير طريقتي تدريب تتظيم السرعة فائق القصر و التدريب التقليدي علي مستويات العامل التغذيـة العصبي المشتق من الدماغ BDNF يتضح من الجدول رقم (10) وجود فروق دالة إحصائياً عند مستوى > 0,05 بين نتائج القياس البعدى لعينة البحث التجريبية والضابطة في متغيرات: عامل التغذية العصبية المشتق من الدماغ BDNF قبل وبعد التمرين لصالح المجموعة التجربيية. يتضـح من نتائج الجدول (8) وجود فروق دالـة إحصـائياً عند مستوى > 0,05 بين نتائج القياسين القبلي والبعدي لعينـة البحث التجريبية في متغيرات: عامل التغذية العصبية المشتق من الدماغ BDNF قبل وبعد التمرين لصالح القياس البعدى يعزي الباحثون الي وجود فروق دالة إحصـائياً لعامل التغذية العصبية المشتق من الدماغ BDNF بين افراد المجموعة التجربية بين القياس القبلي قبل تتفيذ البرنامج وبين القياس البعدي بعد تتفيذ البرنامج إلي اعداد برنامج لتتظيم السرعة فائق القصر وفقاً لكل الارشادات والتوجيهات التي وضعها العالم برنت روشال مؤسس إنس طريقة تدريب USRPT التي ترتبط بين التكنيك ونظم الطاقة خلال السباق الذي يحتاج الي استخدام العقل لتحسين الأداء، وتتميز هذة الطريقة إنها لا يحدث بها ظاهرة التدريب الزائد Overtraining بينما هو ظاهرة عامـة جدا ودائم الحدوث في حالـة استخدام التدريب التقليدي ، نظرا لأن طريقـة USRPT تتجنب حدوث التـدريب الزائـد نتيجـة لتوقف السـباح عـن الاسـمرار في أداء تكـرارات المجموعـة التدربييـة عندما لا يمكنـه الاحتفاظ بسرعة السباحة المستهدفة، وهذه هي خبرة التعب العصبي ولا توجد فرصة لكي يستخدم السباح سرعة سباحة أبطا من سرعة السباق واتفقت النتائج مع ما أظهرته بعض الدراسات أن نمط التفكير الخاص يرفع مستوي الأداء في السباحة بدون جهد وقد ذكرت أنماط التفكير هذه في كتيب رشال وإذا لم يكن لدي السباح استراتيجية تفصيلية للسباق فلن يصل السباح إلي تحقيق أقصي أداء وقد يري البعض أن الكلام مبالغ فيه ولكن كثير من الدراسات أكدت أن هناك فارق بين التفكير التقليدي والتفكير الاستراتيجي وقد يصل تحسن الأداء نتيجة إلي نسبة 2\% ولا يعتبر النشاط المعرفي عاملا محدد لاستراتيجيات السباق كما ظهر اتجاها فسيولوجيا نحو دور المـخ في النشاط البـدني وقد عـرف دور الهـخ في النشـاط البـني للإنسـان منـ تـاريخ طويـل وعن دور النشـاط المعرفي في الاستجابات الفسيولوجية وعن دور الجهاز العصبي في التعب وكذلك دوره في التحكم عمل المـخ وكفايـة استجابات الجسم لشدات حمل التدريب وعن دوره في التعب المستهدف في السباق مثلا ودوره في تناقضـات 
حدود التدريب لتوضيح آليات التعب وهناك قائمسة أعدها Nooks عن كثير من الاستجابات الفسيولوجية التي يطلبها الواجبات البدنية. (3: 154 ) يعزي الباحثون الي وجود فروق دالة إحصائياً لعامل التغذية العصبية المشتق من الدماغ BDNF بين افراد المجموعة التجريبية و المجموعة الضـابطة في القياس البعدي بعد تنفيذ البرنامج لصـالح المجموعة التجريبية إلي اعداد برنامج لتنظيم السرعة فائق القصر USRPT والتي يتضمن اداء العديد من التمرينات التي تعتمد بثكل كبير علي التوافق العضلي و العصبي مثل اداء سباحة الصدر و الفراشـة وغيرهـا من التمرينات التي تتمتع بهذا الحجم من التوافق، وبالاضـافة الي ان طريقة USRPT تعتمد بشكل كبير علي استخدام المـخ وتدريب الجهاز العصبي حيث يقوم المخ بتكوين شبكة من المراكز العصبية النشطة التي ترتبط بنماذج ثابتة لكأداء وهذه الأنماط العصبية ترتبط فقط بمكونـات حمل التدريب الخاصـة بكل مجموعة تدربيية يتم تتفيذها (سرعة السباحة وفترة دوام الراحة وعدد التكرارات ونوع وطريقة السباحة) وسوف لن تتكون هذه الثبكة في حالة التدريب بسرعات أداء مختلفة مثل استخدام مجموعات التدريب التصاعدية أو التتازلية كما يحدث في التدريب التقليدي لكونها لا تعطي الفرصـة للمـخ لتكوين هذه الثبكات العصبية لعدم ثبات سـرعة الأداء وتغيرهـا المستمر ، حيث يتعلم المخ فقط في حالة استخدام سرعات أداء ثابتة وكل ذلك يعمل علي تسهيل مهمه السباح خلال السباق كل ذلك بيعمل علي زيادة معدلات عامل التغذية العصبية المشتق من الدماغ BDNF وعلي عكس المجموعة الضابطة والتي تستخدم التدريب التقليدي بتعتمد بشكل كبير علي تدريب الجهاز العضلي وما يتتج عنه من مخلفات عضلية تؤثر علي الاداء خلال التذريب وخلال السباق واتفقت نتائج البحث مع دراسة Anni Ruostekoski (2017)(7) والذي توكد وجود علاقة قوية بين التمارين الرياضـية وصـحة الدماغ، ويبدو أن الوسيط الحاسـ لهذه العلاقـة حيث أنـه يوجد بـروتين هـام في العائلـة العصبية وهو العامل العصبي المشتق من الدماغ (BDNF)، وقد تبين أن ممارسـة التمارين الرياضية تزيد بشكل حاد من كمية الـ BDNF المنتشرة في الدم، قد يكون مقدار الزيادة في مستويات BDNF يعتمد على كثافة التمرين وقد تلعب متطلبات التمارين الرياضية المُنفذة دورًا أيضًا في كمية الـ BDNF المنتجة، كما قد تلعب مواد أخرى مثل الكورتيزول COR دورًا في تتظيم العامل العصبي المشتق من الدماغ BDNF. ان طريقة USRPT تتأسس علي الاهتمام خلال الوحدات التدريبية بخصوصية نظام السباق من حيث أنظمة الطاقة والاداء الفني والتدريب علي سرعة السباق حيث وجهت الانتقادات للطربقة التقليدية المتبعة في العالم من عام ( 1983) وفقا للطرق التدريبية التي قدمها العالم ماجليشيو حيث انه من ضمن الانتقادات التقليدية بانها لا تتعامل مع خصوصية السباق ولا تعطي فرصسة لتحسين أزمنة السباق و يتعرض كثير من السباحين إلي الاحتراق نتيجة للتدريب الزائد كما يكونوا عرضه لكثير من الاصابات واتفقت نتائج البحث مع دراسة Ferris LT, Williams JS, Shen (2017)(11) بعنوان "تأثير التمرينات الحادة على مستويات العامل العصبي المشتق من الدماغ والوظائف المعرفيـة" وكانت اهم الاستتتاجات ان مستويات BDNF في البشر مرتفعة بشكل ملحوظ استجابة لممارسة الرياضة ، وحجم الزيادة تعتمد على كثافة 
التمرين بالنظر إلى أن BDNF يمكنه عبور حاجز الدم في الدماغ في كلا الاتجاهين ، فإن النتائج التي تعتمد

على الشدة يمكن أن تساعد في تصميم الوصفات الطبية للحفاظ على أو تحسين الصحة العصبية. يتفق الباحثون مـع دارسة روشال 2011 والتي تؤكد علي ان نتيجة تدريب تنظيم السرعة يكون المخ أنماط عصبية عضلية للأداء تربط بين الطاقة وتنكيك الأداء الخاصة بالسباق مما يجعل السباح يقطع مسافة السباق

بسرعة منتظمة وهذا لا يتحقق إلا بعد تكرارات كثيرة لتدريب تتظيم السرعة (17: 121 ) نسب تحسن القياسات القبلية والبعدية لمتغير عامل التغذية العصبية المشتق من الدماغ BDNF يتضح من نتائج الجدول (12) أن نسب التحسن بين نتائج القياسين القبلي والبعدي لعينة البحث في المتغيرات المحددة بالجدول تراوحت بين 611.39\%، 3.04\%. يعزي الباحثون إلي وجود نسب تحسن في المتغير

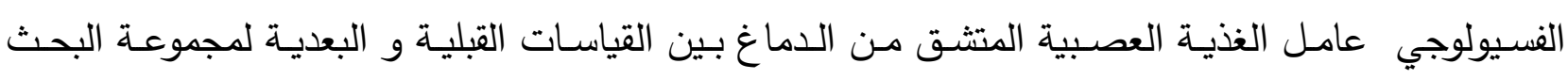
التجريبية إلي اعداد البرنامج التدرببي المقترح لتظيم السرعة فائق القصر USRPT والتي يتضمن اداء العديد من التمرينات التي تعتمد بشكل كبير علي التوافق العضلي و العصبي وغيرها من التمرينات التي تتمتع بهذا الحجم من التوافق، وبالاضـافة الي ان هذه طريقة USRPT تعتمد بشكل كبير علي استخدام المسخ وتدريب الجهاز العصبي بشكل عام، حيث يقوم المخ بتكوين شبكة من الانماط العصبية النشطة التي ترتبط بنماذج ثابتة للأداء وهذه الأنماط العصبية ترتبط فقط بمكونات حمل التدريب الخاصة بكل مجموعة تدريبية يتم تتفيذها

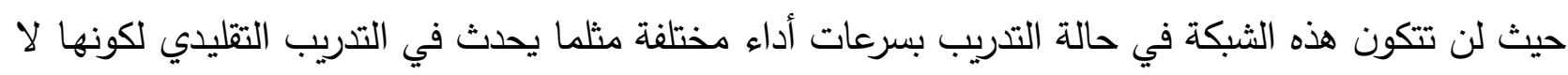
تعطي المخ الفرصة لتكوين هذه الشبكات العصبية لعدم ثبات سرعة الأداء وتغيرها المستمر ، وكل ذلك يعمل علي تسهيل مهمه السباح خلال السباق كل ذلك بيعمل علي زيـادة معدلات عامل التغذية العصبية المشتق

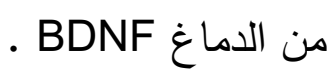
اتفقت تلك النتائج مع دراسة Jennifer L. Etnier, Laurie Wideman واخرون (2016) (14) بعنوان " تأثيرات التمرينات الحادة على الذاكرة والعامل العصبي المشتق من الدماغ (BDNF) وكان الغرض من هذه الدراسـة هو استكثاف العلاقة بين الجرعة والاستجابة بين كثافة التمرين والذاكرة و BDNF، أشارت النتائج إلى أن الذاكرة طويلة المدى كما تم تقييمها بعد تأخير 24 ساعة اختلفت كدالة من كثافة التمرين مـع أكبر الفوائد التي لوحظت بعد تمرين الثدة القصوى، أظهرت بيانات BDNF زيادة كبيرة في الاستجابة للممارسة ومع ذلك ، لم تكن هناك فروق بالنسبة إلى كثافة التمرين ولم تكن هنالك ارتباطات ذات دلالة بين BDNF والذاكرة. هناك ما يبرر البحوث المستقبلية حتى نتمكن من فهم أفضل لكيفية استخدام التمارين الرياضية لفائدة الأداء المعرفي. واتفقت تلك النتائج مـع دراسـة ZOLADZ1,M. GRANDYS واخرون (2008) (13) بعنوان " التدريب المستمر يزيــ مـن تأثير البلازمـا على تثبط العامل العصبي المشتق مـن الدماغ لدى الثباب الأصـحاء " وتهدف الدراسة إلي معرفة تأثير 5 أسابيع من التدريب من التحمل متوسط الثدة على والتغييرات التي تحدث في مستويات BDNF في الشباب الاصحاء وذلك من خلال اجراء برنامج تدريبي على ركوب الدراجات لمدة خمسة أسابيع ، حيث قام ثلاثة عشر رجلا من الثباب الأصحاء النشطاء بدنيا قد بلغ مستويات (BDNF) 
قبل التدريب , 10.3 ـ 1.4 بيكسل، واشارت النتائج الي التدريب ذو القوه المتوسطة يزيد نشاط الـ BDNF] في الثباب الأصحاء واتنقت نتائج البحث مـع دراسـة Anni Ruostekoski (2017) (7) والذي توكد وجود علاقة قويـة بين التمارين الرياضية وصحة الدماغ، ويبدو أن الوسيط الحاسم لهذه العلاقة حيث أنها يوجد بروتين هام في العائلة العصبية وهو العامل العصبي المشتق من الدماغ (BDNF)، وقد تبين أن ممارسة التمارية التبارين الرياضية

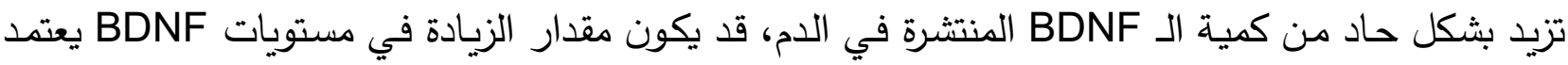

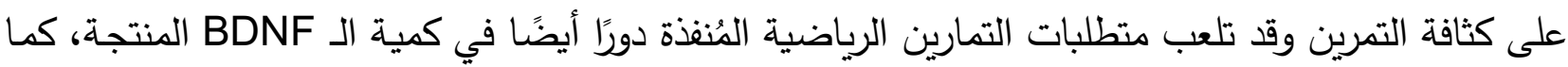

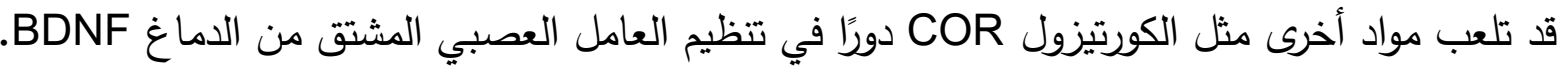

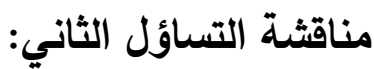
ما هو تأثير طريقتي تدريب تنظيم السرعة فائق القصر و التدريب التقليدي علي المستوي الزمني لمسافة

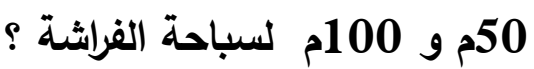
يتضح من الجدول رقم (11) وجود فروق دالة إحصائياً عند مستوى > 0,05 بين نتائج القياس البعدى لعينة البحث التجريبية والضابطة في المستوي الزمني لمسافة 100م لسباحة الفراشة ولاتوجد فروق دالة دالة إحصائياً عند مستوى > 0,05 بين نتائج القياس البعدى لعينة البحث التجريبية والضابطة في المستوي الزمني لمسافة 50م لسباحة الفراشة ويتضـح من الجدول رقم (9) وجود فروق دالـة إحصـائياً عند مستوى > 0,05 بين نتائج القياسين القبلي

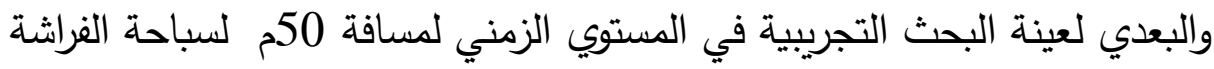

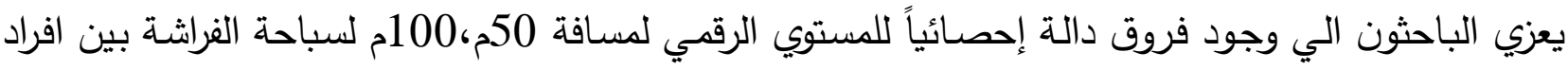
المجموعة التجريبية بين القياس القبلي قبل تنفيذ البرنامج وبين القياس البعدي بعد تتفيذ البرنامج إلي اعداد

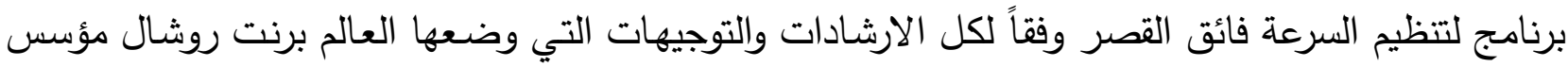
USRPT طريقة تدريب واتقق الباحثون مع رأي روشال 2014 في ان طريقة تدريب USRPT تؤدي إلي نتائج جيدة لسباحي السرعة

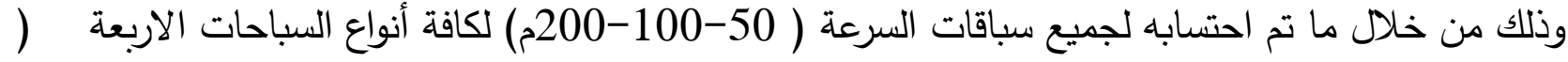

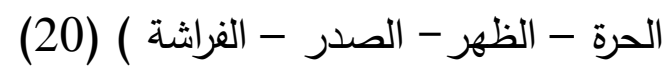

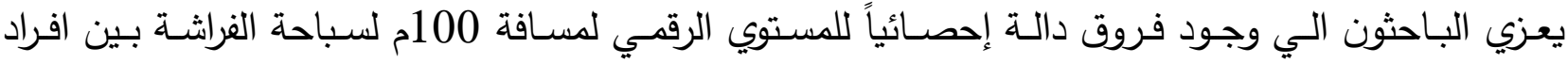

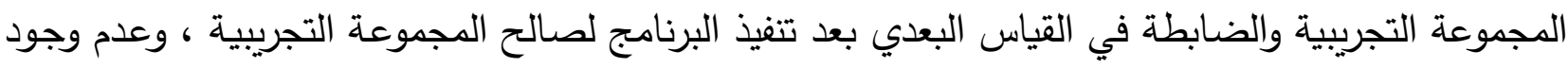

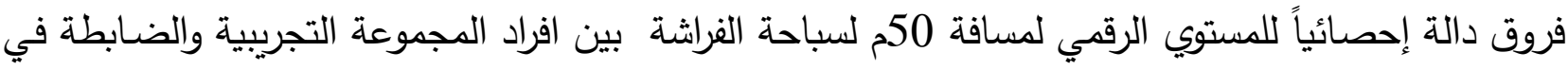

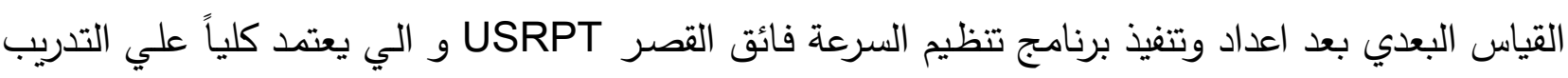
العقلي والذي بدوره ينعكس علي سرعة واداء اللاعب في السباق ، ويبرهن الباحثون وجود فروق دالقدات دالة إحصائياً

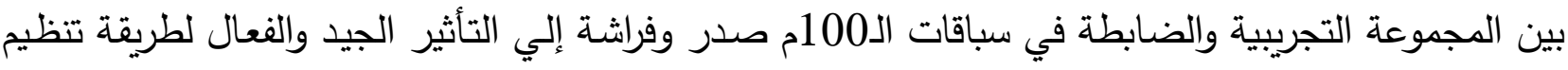
السرعة فائق القصر USRPT والتي كانت تعتمد علي حفظ المخ للاشارات العصبية السريعة التي كان معتاد 
عليها اثناء التدريب وذلك من خـلا السباح أن يتذكر الأزمنة المستهدفة لأجزاء مسافة السباق ويتذكر عدد المحاولات الناحجة وزمن تنفيذ التكرارت الناجحة وكذلك ما أمكن من تسجيله في المحاولتين الفاشلتين حتي يكون ذلك مرجعاً وتحدياً لله عند أداء جرعـة التدريب التالية، ومـن ثم تم اداء السباق بكل سهولة واستندا الباحثون في تفوق سباحين 100م للمجموعة التجريبية عن سباحين 50م الذي لاتوجد فروق دالة إحصائياً بين المجموعة التجرببية و المجموعة الضـابطة إلي ان طريقة تنظيم السرعة فائق القصر USRPT تعتمد علي اداء كل جزء من اجزاء السباق بنفس السرعة الذي بدأ وأنهي بها السباق دون التأثر بالتعب العضلي الناتج عن تلك الاداء وبـالك يكون السباح ادي السباق كله بأقصسي سـرعة ممكنـه علي عكس السباحين الذين يخصسون للتدريب التقليدي يؤدون السباق بسرعات مختلفة يرجح ذلك علي تراكم حامض اللاكتك وظهور التعب اثناء السباق والذي بدورة بينعكس علي تقليل سرعة السباح في معظم اجزاء السباق وهذا بيختلف كلياً

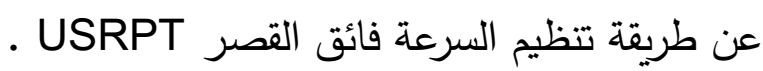
وتتفق نتائج البحث مع دراسـة دراسـة محمد أحمد عبدالله وأبو العلا عبد الفتاح (2015) (2) وعنوانها " دراسـة تأثير تدريبات تتظيم سرعة السباق بالمسافات أقل من القصيرة علي مستوي الأداء في السباحة " والذي كان من اهم نتائجها استخدام تدريبات تتظيم سرعة السباق بالمسافات أقل من القصيرة إلي تحسن مستوي الأداء في السباحة كما يقاس بزمن أداء مسافة السباق أفضل من تدرببات السباحة التقليدية لدي السباحين و السباحات. وايضا اتفقت النتائج مع دراسة محمود محمد سيد دياب ( 2017 ) (5) بعنوان " تأثير التدريب بفترات الراحة و المسافة فائقة القصر بسرعة السباق و التدريب التقليدي علي بعض متغيرات الأداء و المستوي الرقمي لسباحي الزحف علي البطن " والذي كان من اهم نتائجها تحسن جميع الأزمنة الرقمية في المسافات المحددة بالدراسة والتي كان يستخدم فيها نظـام التدريب بتتظيم سرعة السباق USRPT عن الأزمنـة الرقميـة في المسـافات المحددة بالدراسة والتي كان يستخدم فيها نظام التدريب التقليدي. وتوافقت نتائج البحث مع دراسـة مدحت ثابت ثابت علي ( 2017 ) (6) بعنوان " تأثير التدريب التخصصي في السباحة علي مستوي الأداء الفني وبعض المتغيرات الفسيولوجية " والذي كان من اهم نتائجها كالاتي دأي تؤدي طريقة تدريب USRPT الي تحسن مستوي الاداء الفني والمستوي الزمني و حدوث تحسن في التحمل الخاص بالأداء لمسافة السباق التخصي واداء مسافات اطول لضربات الرجلين تحت الماء الذي يدل علي حدوث تكيف فسيولوجي باستخدام طريقة تدربب USRPT ويعزز الباحثون نتائجه إلي ان التدريب التقليدي الذي يعتمد علي أداء تدريبات غير مرتبطة بسرعة السباق إلي تحسن أداء السباح في أداء المجموعة التدريبية أي أنه يتدرب ليصبح أحسن في التدريب وليس السباق فهو يصبح جيدا ومتكيفا مـع التدريب لمدة سـاعتين فقط ولكنه لا يكون متكيفا لأداء السباق بسرعة عالية لمدة

$$
\text { دقيقتين فقط أو أقل. (18 : } 277 \text { ) }
$$

وأن جميع هذه الدراسات تدعم فكرة الدراسة قيد البحث وتساعد الباحثون في التحقق من فروض وأهداف البحث

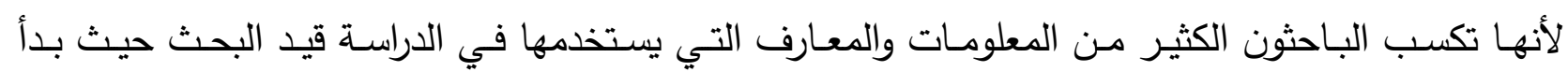
الباحثون من حيث انتهي الأخرون. 
نسب تحسن القياسات القبلية والبعدية لمتغير المستوي الرقمي لمسافة 50 ، 100م لسباحة الفراشة.

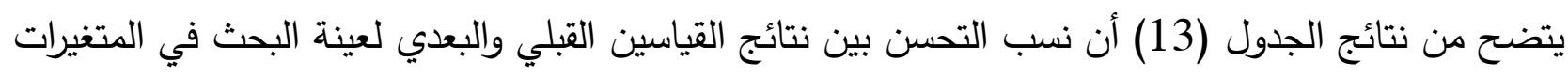

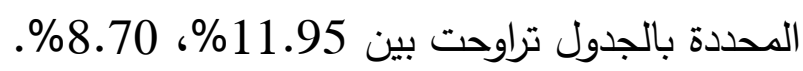

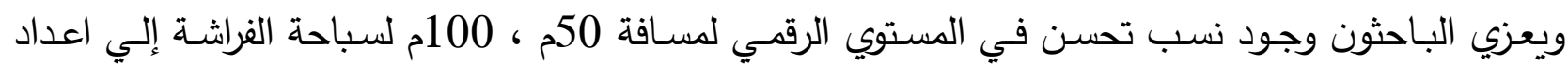

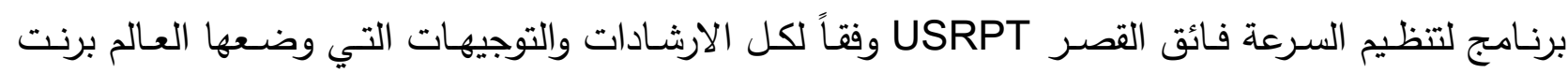
روشال مؤسس طريقة تدريب USRPT والتي ترتبط بين التكنيك ونظم الطاقة ، ولكن السباق أيضا يحتاج الي لئي

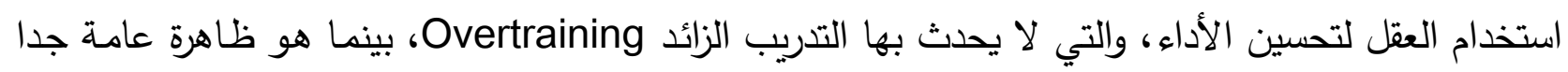

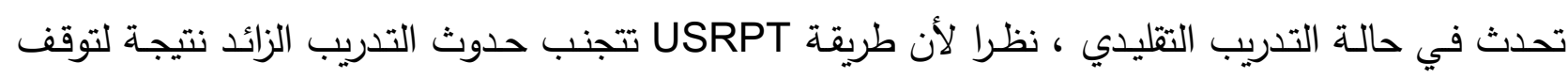

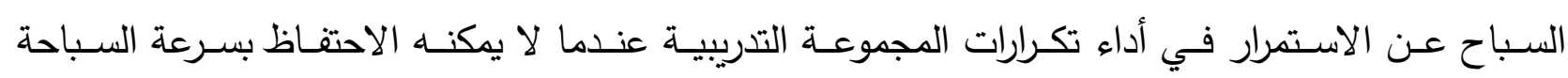

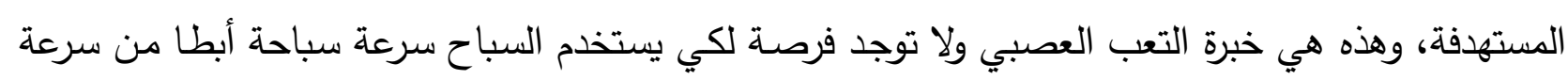
السباق.

واتفتت تلك النتائج التي حدثت في تحسن المستوي الرقمي مع دراسة أبو العلا عبد الفتاح ومحمد حامد فهمي

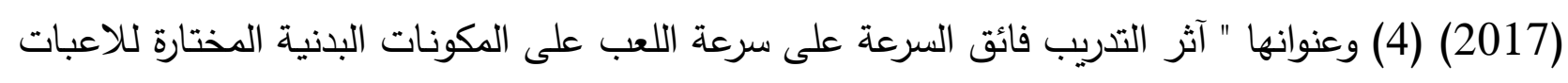

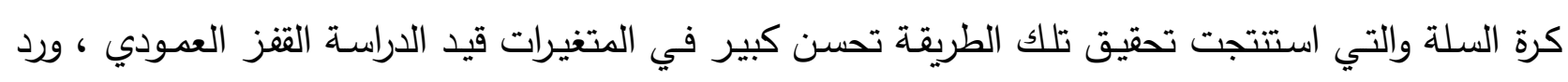
الفعل - اختبارات الوقت والتسارع وخفة الحركة واختبار الاسترداد المتقطع.

الأستنتاجات

في حدود عنية البحث و الأدوات المستخدمة في مجال البحث و الهدف منهـ وفي ضوه تساؤلاته ، و

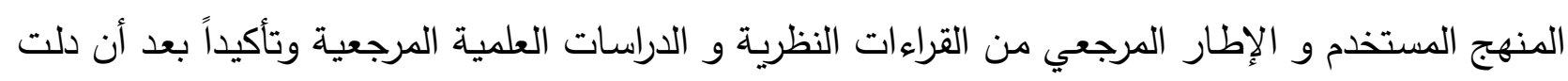

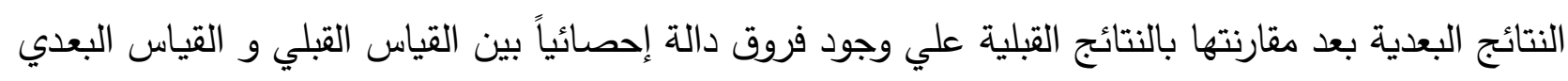

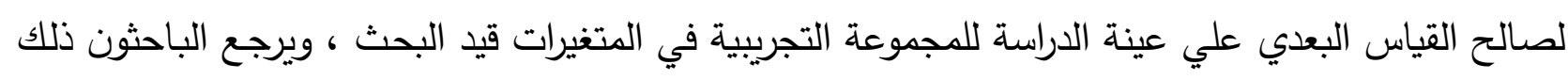

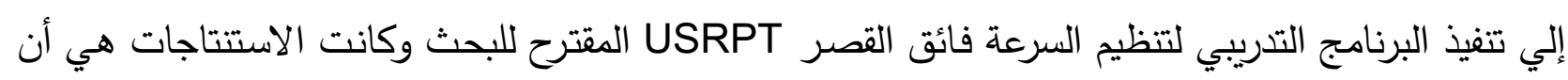

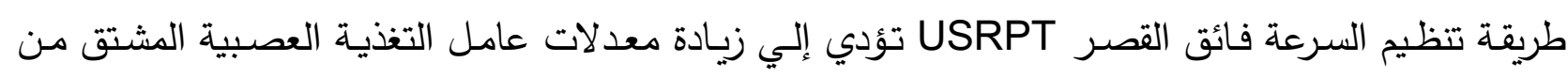

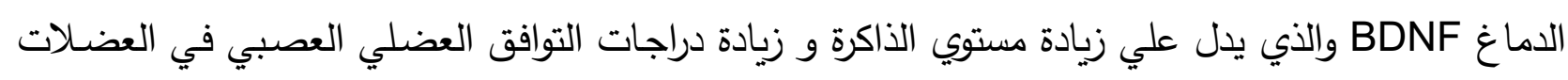
العاملة مقارنتاً بطريقة التتريب التقليدي طريقة تتظيم السرعة فائق القصر USRPT تؤدي إلي تحسن المستوي الرقمي للسباحين في مسافة 50 و 100

التوصيات

إستتاداً إلي البيانات والاستنتاجات التي إنتهي منها الباحثون، و في حدود عينة البحث التي أجريت عليها

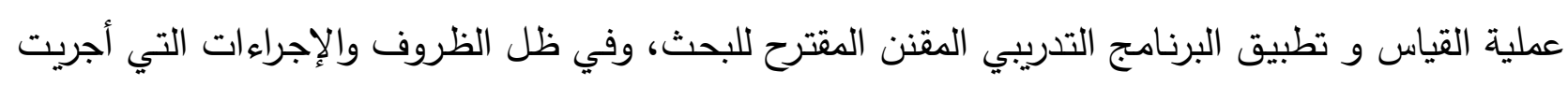
فيها هذه الدراسة يوصي الباحثون بما يلي : 
• تطبيق البرنامج التتريبي المقترح لتنظيم السرعة فائق القصر USRPT قيد الدراسة لما لله من تأثير إيجابي علي عينة البحث في كافة النواحية الفسيولوجية والرقمية.

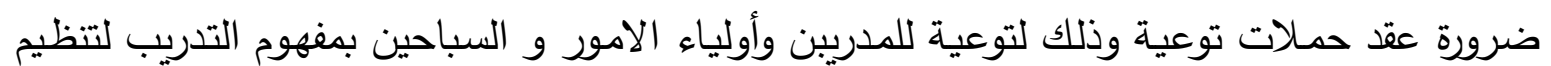
السرعة فائق القصر USRPT والذي يحقق أفضل نتائج بشكل مستمر ، علي عكس التدريب التقليدي

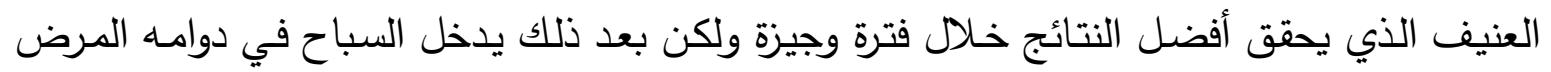
والتي تقضي علي مستقبله الرياضي •

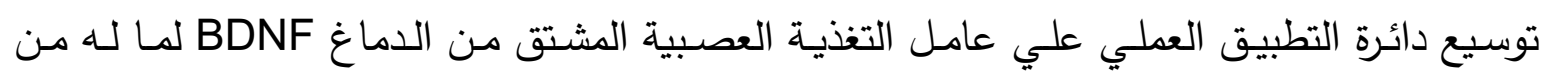

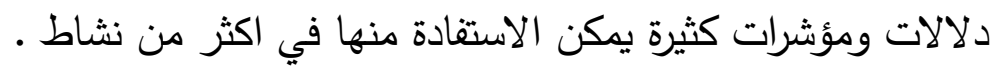

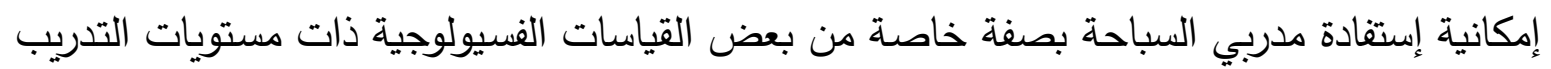

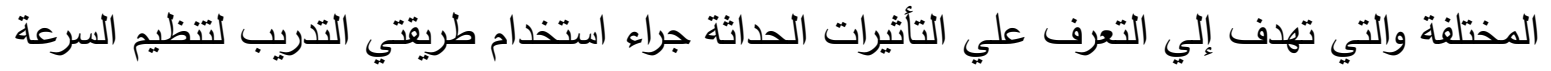
فائق القصر USRPT و التدريب التقليدي .

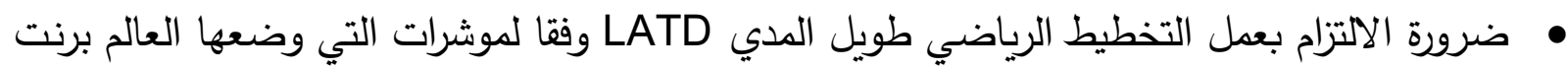

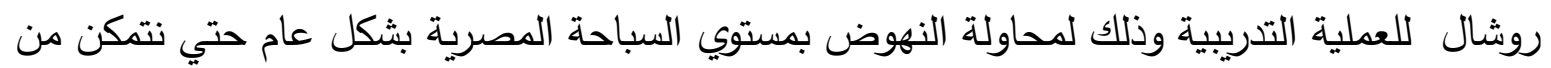
الوصول لأفضل النتائج في المسابقات العالمية.

قائمة المراجع العمية أولا : اولا: المراجع باللغة العربية : العهاه

: الاتجاهات المعاصرة في تدريب السباحة ، دار الفكر العربي ، القاهرة.

: دراسة تأثير تدريبات تنظيم سرعة السباق بالمسافات أقل من القصبرة علي مستوي

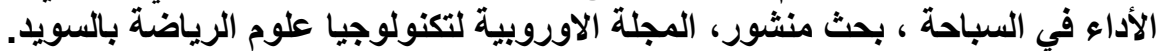
(2011) - 2- أبو العلا عبد الفتاح

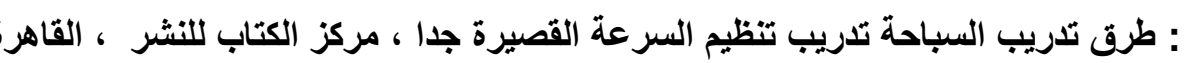
محمة أحمد عبدالله (2015)

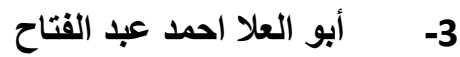
برنت روشال (2016)

: آثر التدريب فائق السرعة على سرعة اللعب على المكونات البلنية المختارة للاعبات كرة السلة دراسة تجريبية ، بحث منشور، كلية التربية الرياضية حلوان.

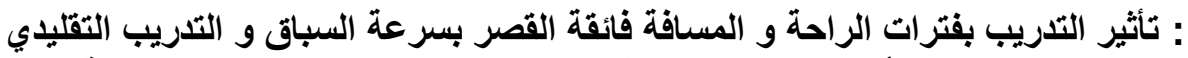

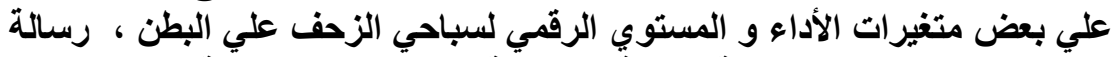

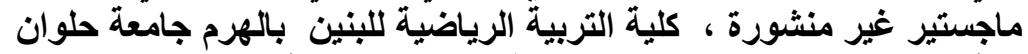

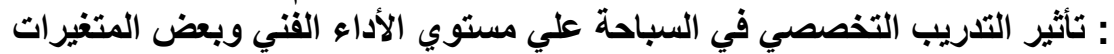

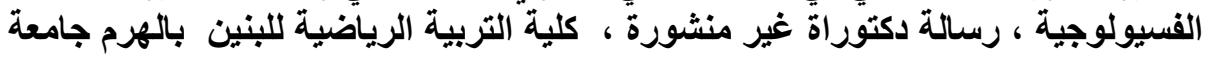
ثانيا : المراجع باللغة الاجنبية

7-

Anni Ruostekoski :The Effect Of Exercise INTENSITY and Exercise Environment on

(2017) Brain Derived Neurotropic Factor (BDNF) and Physiologic Parameters in Young Male Skier ، Master's Thesis Exercise Physiology Faculty of Sport and Health Sciences University of Jyväskylä 
8- $\quad$ Bamji SX, Rico B, Kimes N, : BDNF mobilizes synaptic vesicles and enhances synapse Reichardt LF (2006) formation by disrupting cadherin-beta-catenin interactions. J Cell Biol; 174: 289-299.

Bekinschtein $\mathrm{P}, \quad$ : Persistence of long-term memory storage requires a late protein Cammarota M, Igaz, synthesis- and BDNF- dependent phase in the hippocampus. Medina JH (2007) Neuron; 53: 261-277.

$10-$

11-

12-

13-

14- Jennifer L. Etnier, Laurie Wideman, Jeffrey $D$. Labban, Piepmeier, Daniel M (2016)

15- Maglishco.E.W(2003)

16- Maglishco (2013)

17- Rushall, B, S. (2011)

18- Rushall, B, S. (2013)

19- Rushall , B, S. (2013)

20- Rushall, B, S.(2014)

21- Rushall, B, S.(2018)
: U.S.R.P.T Ultla Short Race Pace Training A statement conviction, Australia.

: The effect of acute exercise on serum brain-derived neurotrophic factor levels and cognitive function. Med Sci Sports Exerc; 39: 728734.

https://en.wikipedia.org/wiki/Brain-derived_neurotrophic factor

: ENDURANCE TRAINING INCREASES PLASMA BRAIN - DERIVED NEUROTROPHIC FACTOR CONCENTRATION IN YOUNG HEALTHYMEN, JOURNALOF PHYSIOLOGYAND PHARMACOLOGY, 59, Suppl7, 119-IJ

: The Effects of Acute Exercise on Memory and Brain-Derived Neurotrophic Factor (BDNF) the University of North Carolina at Greensboro, Greensboro, NC. Address author correspondence to Jennifer L. Etnier at jletnier@uncg.edu

: Swimming Faster the essential ref.enceon technique, Magfill publishing co, California U.S.A

: part1 : training fast twitch muscle fibers: why, when and how, swimming coach journal, vol 18

: Commentary on the long term athlete development model for British swimming and the misinformation it propagates.

Swimming Science bulletin 38 \{ http//coachsci.sdsu.edu/swimming/ bullets/table.htm \} : A swimming technique macro cycle. Spring valley, AC : sports Science Associates \{http//brentrushall.com/macro.htm\} : relevant training effects in swimming pool (USRPT) Swimming science blue time

: swimming energy training in the 21st century : the justification for radical changes (second edition )

:step by step (USSPT) planning and decision making process and example of ( USRPT) training session microcycls and techniques instructions, swimming science blue time 